\title{
The Objectivity of Ordinary Life
}

\author{
Sophie Grace Chappell ${ }^{1}$
}

Accepted: 3 March 2017 /Published online: 29 April 2017

(C) The Author(s) 2017. This article is an open access publication

\begin{abstract}
Metaethics tends to take for granted a bare Democritean world of atoms and the void, and then worry about how the human world that we all know can possibly be related to it or justified in its terms. I draw on Wittgenstein to show how completely upside-down this picture is, and make some moves towards turning it the right way up again. There may be a use for something like the bare-Democritean model in some of the sciences, but the picture has no standing as the basic objective truth about the world; if anything has that standing, it is ordinary life. I conclude with some thoughts about how the notion of bare, "thin" perception of non-evaluative reality feeds a number of philosophical pathologies, such as behaviourism, and show how a "thicker", more value-laden, understanding of our perceptions of the world can be therapeutic against them.
\end{abstract}

Keywords Metaethics · Moral philosophy · Moral realism · Moral subjectivism · Wittgenstein · Thick concepts $\cdot$ Behaviourism $\cdot$ Problem of other minds

What has to be accepted, the given, is—so one could say-forms of life.

(Wittgenstein, Philosophical Investigations, II, p. 226)

I noticed once again how all thought among us had become "something other than human life".

(W.B.Yeats, Notes in his Collected Poems)

1

Please imagine two possible worlds. One world is an atoms-and-the-void world, a world of mindless simple particles spinning randomly through empty space (I would put "empty black

My thanks for their comments to Alice Crary, Herman Philipse, and the participants in the "Ethics and objectivity" conference in Utrecht, March 2016, where this paper was first presented.

Sophie Grace Chappell

sophie-grace.chappell@open.ac.uk

1 The Open University, Milton Keynes, UK 
space", but this world knows only primary qualities): a world of nothing but basic Newtonian or perhaps quantum mechanics operating on nothing but the simplest possible dots of lifeless matter. I could go on describing it, but I think readers, especially readers of Democritus, or of modern physics, or of certain modern philosophers, will already know the world I mean.

The other world is, as we may call it, the world of War and Peace: a world of lovers and battles, romantic hopes and unromantic doubts, pecuniary cares and political fears, rapture and ennui, taciturn rationalist fathers and fulsome fideist sons, partings in drunkenness and reunions in sobriety, social pride and the peasant's pride in a good scythe-action, the beau monde and the demi-monde, the emperor and the nursery-girl. And again, I could multiply descriptions, but readers will already get the idea.

The atoms-and-the-void world and the War and Peace world: which of these two worlds is our world (more or less)? Which of these two worlds do we already know? Which of these two worlds stands in need of justification and vindication by reference to the other? I hope the answer is as obvious to the reader as I mean it to be. The human world that we all of us inhabit is, more or less exactly, the War and Peace world. We may not have emperors or courtiers or nurseries or serfs any more, not at least here outside Russia, but the abiding power of any great novel rests at least partly on its power to evoke recognition in the reader: recognition of the gemeinsame menschliche Handlungsweise, "the common human way of going on" (Philosophical Investigations I, 206), that is shared by all of us, including you, me, and Natasha Rostov. So we may also call the War and Peace world the human world.

(And if I may register a quick terminological grumble, let's please not call it "the folk world". It's not clear who started this locution - the earliest use of it I've found so far is in the title of Stich's book From Folk Psychology to Cognitive Science (MIT 1983) ${ }^{1}$-but references to the folk this and the folk that are now all-pervasive in philosophy. Nothing strikes us philosophers today as more natural than to constitute ourselves as an elite of quasi-scientific experts, and our fellow-citizens as a wayward tribe of quaint but exotic primitives to whom we stand as parachuted-in anthropologists (with or without pith helmets). Government House lives. This burgeoning self-image of ours isn't merely condescending, it is positively neocolonialist. Above all it falsifies, by missing or obscuring the exceedingly obvious point that we are the folk. We philosophers too, for all our alienation and ever-so-sophisticated shudderquoting, are users of the concepts that we are studying.)

Enough grumbling already. Back to the main point. There may be a use or a place for the Democritean atoms-and-the-void world. But it cannot be used or situated as the objective truth about reality, relative to which the human world needs to justify and vindicate itself. On the contrary, the Democritean world needs the human world's vindication. What kind of justification could there be, anywhere or at any point, for seeing things under the aspect of atoms and the void? There could be a justification for adopting that vision sometimes: when doing particle physics, for instance. But that justification would itself come from, and presuppose, the War and Peace world.

If the Democritean world is real at all, it is real only as a part of the human world, or better perhaps as an aspect of it. Better still, we can say that the Democritean world is an abstraction from the human world; it is a focusing on (at most) one particular kind of truths about that world, for (at most) one particular kind of valid scientific purpose. Therefore I may say, using a

\footnotetext{
${ }^{1}$ The philosophers' phrase "folk psychology" may have been coined by analogy with "folk etymology", which is a strongly pejorative phrase - folk etymologies are always wrong in process, and usually wrong in output. The term "naïve psychology", frequently used among psychologists, is no less patronising.
} 
favourite word of philosophers - though not perhaps the way they would like me to use itthat the human world grounds the Democritean world. So if objective truth is possible about the Democritean world, it is possible only because objective truth is already possible about the human world. For objective truth starts where we all know it starts (at least until we start doing philosophy): in ordinary basic human-world exchanges and observations. "Natasha is sad", "Pierre is thinking", "Nikolai is wounded", "Prince Andrei is contemptuous of his wife": statements like these - at least when they are about a real reality rather than a fictional oneare the most immediately accessible objective truths there are. Our ability to get hold of objectivity anywhere is a skill we learned by getting hold of objectivities like these. Insofar as we can understand and assign a truth-value to (updated) Democritean-world statements like "Fermions have half-integer spin while bosons have integer spin", our ability to do that presupposes our antecedent ability to grasp and judge true or false statements from the human world.

In light of these thoughts, we might want to establish a vocabulary for talking about such objectivities of the human world as facts about people being happy or indignant or in pain or hopeful (and so on). If we want to appeal to what is natural, we might say that facts like these are the most obviously natural things around us, and base an ism - naturalism - on that observation. If we find it helps us to use metaphors like "the furniture of the world" or "the fabric of reality" as aids to picking out what is "really there", then we might apply them to instances of happiness, indignation, pain, hope, and so forth. If anything is part of the furniture of the world, "really there", then these things are. And then the naturalist will be the philosopher who starts from them.

Such a philosopher may also have some worries about queerness and spookiness and mystery elsewhere in her picture, away from the objectivity of ordinary life in which she begins. For instance, if anything looks queer or spooky or mysterious, bosons and fermions most certainly do. (Never mind wave-particle duality, action at a distance, and other clear examples of "magical" behaviour at the quantum level.) She may, correspondingly, see difficult questions about our epistemic access to the weirder and more arcane postulates of some kinds of science.

Where she won't see a problem of epistemic access is in ethics; for the vocabulary in which we speak of the objectivities of ordinary life is already "ethically charged". (As philosophers tend to call it; most other people do not see any clear distinction between the ethical charge and the thing that has this charge.) To speak of pain is already to speak of something apt to call for consolation; to speak of indignation is already to speak of a judgement of injustice with which we may or may not agree that founds an emotion with which we may or may not sympathise; to speak of hope is already to speak of longing, with more or less possible warrant, for a good thing to come. (Philosophers have argued at some length about whether desire necessarily happens "under the guise of the good"; one strong argument for thinking that it must, is that all the other non-epistemic propositional attitudes happen either under the guise of the good, like hope, or under the guise of the bad, like fear.) There are ethical reasons and values present in all these attitudes - and present right there in them, right here in the world with us where we are. To "get to" these values is not to whizz off on some philosophical magic carpet to some dubious Platonic hyper-realm. It is merely to see what's right there in front of our noses. As Iris Murdoch says, there is "no impersonal world of "facts" ( $S G$ 25), no thin reality consisting (perhaps) of a mere catalogue of objects in space and nothing else; or if there is, it is an abstraction from the reality we actually know, and as such perhaps poses its own problem of epistemic access. The reality we know is not thin but thick; the evaluative and the prescriptive 
are as fundamentally part of it as any catalogue of objects in space. Actually even the idea of cataloguing objects in space presupposes some purpose for which those objects are catalogued: even here, as everywhere, Vorhandenheit presupposes Zuhandenheit and not the other way round.

The human world, the world of ordinary life, the War and Peace world: this is also the world that Jerry Fodor is talking about when he writes, in a well-known passage in Psychosemantics, the following summary of some of the action of one of Shakespeare's best known plays (see Midsummer Night's Dream Act 3 Scene 2):

Hermia has reason to believe herself beloved of Lysander. (Lysander has told her that he loves her-repeatedly and in elegant iambics - and inferences from how people say they feel to how they do feel are reliable ceteris paribus.) But if Lysander does indeed love Hermia then, a fortiori, Lysander wishes Hermia well. But if Lysander wishes Hermia well, then Lysander does not voluntarily desert Hermia at night in a darkling wood. But Hermia was, in fact, so deserted by Lysander. Therefore not voluntarily. Therefore involuntarily. Therefore it is plausible that Lysander has come to harm. At whose hands? Plausibly at Demetrius' hands. For Demetrius is Lysander's rival for the love of Hermia, and the presumption is that rivals in love do not wish each other well... Knowing and believing all this, Hermia infers that perhaps Lysander has killed Demetrius. And we, the audience, who know what Hermia knows and believes and who share, more or less, her views about the psychology of lovers and rivals, understand how she has come to draw this inference. We sympathise.

I mean, also, the world that Iris Murdoch is describing in the following passage from The Philosopher's Pupil (pp.339-341), where Murdoch narrates how a nice middle-class lady Gabriel has "a terrible experience": she happens on two (implicitly) rather yobbish youths at the seaside who have caught and confined a large fish in a small and stagnant rock-pool. Gabriel is so distressed by the fish's distress that she pleads with her husband, Brian, for money:

"Some boys have got a fish, a live fish, I want to buy it to save it--"

"Two pounds, for a fish?"

"I want to buy it, to put it back in the sea."

"Oh, don't be silly," said Brian, "we're not made of money. Certainly not."

Gabriel turned from him and ran on laboriously, her feet sinking in the sand, her face red with tears.

As any filmgoer or playgoer or reader of novels or poems is already aware, this world that Fodor and Murdoch and I are talking about is, pervasively and constitutively, shot through with values; has values in its very warp and woof. To love someone is to wish her well; so to be loved is to have reason to think yourself wished well. To have a rival for someone's love is naturally to envy him; to envy someone is, or can easily be, to wish him harm; so to know that your lover (the one you choose) has a rival, and that his rival is powerful and malicious, is to have reason to fear for your lover. Or again: to see a fish that has been captured and is being treated cruelly is naturally to feel pity for it (at least, this response is natural for anyone like Gabriel); and to pity it is naturally to want to save it. But such an impulse can seem sentimental and silly to others; at the very least its occurrence raises the question what counts as sentimentality or silliness, and what counts as fine responsiveness to a beautiful and helpless creature. (It also raises the question whether the thick concepts "sentimentality" and "silliness", 
as they occur or implicitly occur in the Murdoch passage, should be in our moral vocabulary at all; especially "silliness", which seems in this context to be pretty clearly a sexist criticism.)

When we try and spell out the thought of these two passages, there is normativity of all sorts - values, virtues and vices, goodness and badness, benefit and harm, thick concepts, reasons not only prudential but both moral and epistemic too - to be found in them everywhere we look. Yet while both passages are of course records of dramatic events, ones worth the narrative artist's effort to record, there is nothing atypical about these events; just these types of events, and ones just like them, are the very warp and woof of all human lives.

It would be an interesting exercise to try and catalogue systematically all the ways in which the fabric of ordinary human lives is typically constituted by values, and unthinkable without them: which means, in particular, unredescribable without essential loss in a value-free version. There is much more to say about this that I have space for here, but at least all the following claims are true (and of course so interconnected that it is not all that easy to keep them separate) about how values are there in ordinary human life:

1. Reasons to act, react, empathise, and identify. The experience of seeing something as naturally evoking a response from me, such that I would be wrong if I didn't so respond, is everywhere in human life: arrogance calls for gentle correction, sorrow calls for pity, witnessing someone's anger or anxiety leads us directly to asking whether it's justified, whether we would feel the same in her shoes, etc.

Further, and in particular,

2. Pain: there is no corresponding truth about pleasure (except perhaps that we shouldn't prevent it unnecessarily), but it is clearly and obviously true that when someone else is in pain, that description alone gives us ceteris paribus reason to avert or mitigate or prevent it if we can. If any reason is, this one is all the things that Mackie famously requires "special moral reasons" to be: it is not conditionally dependent on desire, it is directly and immediately cogent for us (ceteris paribus), and it is universalisable-anyone in my situation would have this same reason (again, ceteris paribus). Does that make our reason to avert or prevent pain "queer" or unintelligible? On the contrary-it's one of the most familiar things there is. But does it mean that it's hard to fit this reason into "the furniture of the world"? Well here as elsewhere the answer to this is as before: if the furniture of the world means bare atoms and the void, then sure, but nothing else fits easily into that world either; or if the furniture of the world means the human world as we know it - not in the least.

3. Epiphanic perceptions. We just see a value, in a moment of revelation. This happens. Not all the time; but often. (And its not happening oftener may well be less about the unavailability of such experiences, and more about our obtuseness.)

4. Thick concepts. The descriptions above give us (romantic) love, vulnerability, desertion, rivalry, anxiety, sympathy, cruelty, callousness, unkindness, price, saving, silliness, sentimentality, pity. To think in terms of concepts like these is obviously and necessarily to think in normative terms. Human life is not reconceivable without them; there is no conceivable human life which is just what it is except it doesn't have these bits - no human world from which these and the like concepts have simply been surgically removed.

5. Harm and benefit. As Philippa Foot has often argued, these basic ethical concepts are pervasive because they interfuse so many other concepts of our moral and practical 
psychology. As a matter of logical grammar, there is no anxiety or fear or even envy without the prospect of harm to someone. For Hermia to say "I am anxious for Lysander" while denying that she thinks or feels that any harm at all threatens or may possibly threaten him is for Hermia to misuse the word "anxious"; for Gabriel to say that she wants to "save" the fish, while denying that there is anything at all that the fish needs to be saved from, is for her to misuse the word "save".

6. Desires. Our appetitions are themselves a study of how ordinary life is charged with the normative; the more one thinks about the detail of the structure of our desirings, the less plausible becomes the philosophers' doctrine that desiring is really what all proattitudinising reduces to. In typical cases, we want things for reasons, and those reasons refer to aspects of the thing wanted that make it worth having. (Yes, of course there are brute blind impulses or compulsions as well under the heading of desire. But these are atypical, both because they're less common, and also because by definition a desire of mine is something that I am myself involved in, something that originates in me; brute impulses are not so much our desires as desires that happen to us.)

7. Roles. Occupying certain roles gives us reasons to act in certain ways. If you are the lifeguard, you have reason to rescue surfers caught in rips that other people don't have. Similarly,

8. Practices: the fact that you are involved in a MacIntyrean practice gives you ceteris paribus reason to seek excellence in that practice; to play tennis or chess is to be committed, at least in some minimal sense, to trying to play it at least reasonably well.

9. Promising and other moral institutions: the fact that you have promised to do something (where what you've promised to do is not itself morally illegitimate) generates a reason why you should do it that non-promisers do not have.

10. Brute-fact relations. Anscombe's famous Analysis paper "On brute facts" argues that, given certain facts at one level (e.g. the grocer has put $50 \mathrm{lb}$. of potatoes in my porch, as he does every first Tuesday in the month, and potatoes cost 20p per lb), certain other facts at another level can be inferred (e.g. that I owe the grocer £10). Anscombe is, surely, absolutely right that this kind of sociological relation is indeed crucial to explaining one way in which moral relations and realities emerge out of relations and realities at lower orders.

... And so on. There have been a number of efforts to "cross the is-ought gap" using just one of these stepping-stones, or siege-ladders. My point is that these are all ways across it; or rather, that we never find ourselves purely on the "is" side of it in the first place. As a matter of the living of ordinary life, the is-ought gap is overwhelmed from every side. If there is a gap, our difficulty is usually not how on earth we are to get from the descriptive to the normative side. We are already in a world with a value-dimension. (We live there. It's our home.) Hence it is going the other way, stripping this out of the world and trying to understand reality around us without that dimension, that is problematic.

In human life as we actually experience it, there usually isn't an is-ought gap at all; there is an is-ought continuum. There is an almost constant toing and froing, perfectly natural and quite untroubled by sceptical doubts, between "non-evaluative" (or less evaluative) and "evaluative" (or more evaluative) descriptions. The world, as Heideggerians say, is for us a matter of concern: we experience the world as value-laden, and value-laden from the bottom up; as drenched in value. What needs justifying, for us, is not the human world, but the kinds of abstraction from it that we might call "scientific worlds". 
Relative to the standard picture in contemporary philosophy, what I've just said is, of course, rankly heretical. On that picture it is ordinary life that needs to justify itself relative to the standards or imagined standards of "science"; if any picture is supposed to be unquestionable, it is the Democritean picture or something like it; everything we ordinarily think we know from our experience is supposed to be put in doubt by that. And though I have sometimes called my version of Wilfrid Sellars' "manifest image" the War and Peace world, Tolstoy himself is a famously shaky ally for my purposes. For the philosophical point of War and Peace is not at all what you might expect it to be, from the overwhelmingly vivid and beautiful humanity and humaneness of the main narrative. Rather, as Tolstoy tells us in his famous Epilogue, the philosophical point of his novel is very mid-nineteenth-century one: it is a crude and absolute historical determinism. Whether humans are at war or at peace, their lives (he thinks) are governed and driven by a hidden necessity, the causal necessitation of a Laplacean universe. Tolstoy believes that this engine of hidden necessity always underlies the human life that he so movingly and exactly portrays, and sometimes is actually visible within it. We glimpse the engines when Pierre, attending a society dinner, finds himself swept into betrothal to Hélène Kuragin no matter what he does, and whether he likes it or not. We glimpse them again the night before Austerlitz, as the Austrian and Russian generals engage in futile intricacies of tactical arrangement for a battle that they are sure they will win-from which discussions the sage old peasant-born Kutuzov, the one general present who actually understands the deterministic reality of war, and who therefore realises that the allies are going to lose no matter what cunning plans they choose to concoct, absents himself by simply going to sleep. A third example, one with application in both war and peace, is the curious hobby-horse that Tolstoy so insistently rides through his greatest novel about medicine. Health and illness, life and death, he tells us again and again, will be what they will be irrespective of the choices of mere individual doctors. (No doubt this view was less cranky in 1865 than it is now, and less cranky still in 1806. After all, in 1806 it was standard practice for a doctor to go round a field of fallen soldiers, exsanguinated and desperately dehydrated, and-bleed them.)

This tension in Tolstoy between the human world and the world of determinism is not, of course, a problem for my argument that I have carelessly just stumbled into. Actually the tension is one of the main reasons I invoked him, rather than some other novelist, as a portrayer of the human world. The tension is, among other things, a tension within the novelist himself: Tolstoy the aesthete versus Tolstoy the ascetic, Tolstoy the hero of the literary scene versus Tolstoy the reclusive fanatic, Tolstoy the gentle and humane observer versus Tolstoy the narrow, bigoted crackpot. Perhaps this tension has something to tell us about ourselves.

My adjectives may seem to leave no doubt "which side I am on" about this tension. But the real point is not so much to take sides, as to question whether there are sides to be taken here at all. To put the point rather broadly and crudely as a first pass: we do not face a choice between believing "the manifest image" and believing "the scientific image". (Pace Sellars, with whom I would be parting company here if I hadn't pretty obviously done so already.) Unless the structure of reality itself is logically fractured, one well-grounded certainty cannot drive out another. And the first of all well-grounded certainties is that our human world is real: we really do live together in a shared world of loves, hates, hopes, fears, wishes and desires, dislikes and aversions, pleasures and pains. If science provides us with certainties too- and no doubt it does - those certainties have to be consistent with our humane certainties. Science can put us in no position to deny wholesale the existence of other minds (or indeed of minds in general 
including our own), the reality of choices where one "could have done otherwise", or the existence of intentional psychology (what some philosophers dismissively call "folk psychology"). For that there are such realities is part of the framework of understanding within which we (some of us) begin to be scientists at all.

Even to those who share my taste for philosophical heresy and a bit of épater les bienpensants, these first two sections perhaps sound too extreme and too dogmatic. Maybe it's a case of fighting fire with fire; it's not as if reductionists and eliminativists had never overstated their case in the interests of raising the rhetorical temperature. But speaking fully seriously, I don't really want to rule out absolutely the possibility that scientific discovery or reflection might lead us to revise our understanding of the humane world. On the contrary: discovery and reflection can always lead us to revise our understanding, and scientific discovery and reflection can do this just as much as any other kind of discovery or reflection. But typically they do so piecemeal, not wholesale; we come to see some particular concept or mental tool in a different light, not the very idea of a concept or a mental tool. ${ }^{2}$ And typically such discoveries explain, they don't explain away. Pace so many authors, to understand the evolutionary origins of altruistic behaviour is not to understand that really altruistic behaviour is a disguised form of self-seeking, any more than to understand the evolutionary origins of a foot in a flipper is to understand that in reality there are no feet-all feet are really disguised forms of flippers. Typically, therefore, such discoveries are not, in the classic sense of the term, "reductionist" discoveries. Unless they are covertly aided and abetted by the genetic fallacy, they don't show that everything in some realm of inquiry has to be understood exclusively in the terms whereby we understand the origins of that realm of inquiry. What they show is how it became possible for a new realm of inquiry to emerge from a pre-existing pattern of some sort. (Music may have originated in the crooning of one ape-man to another as they engage in mutual grooming activities. It doesn't follow that there is no more to say about a Bach partita than can be said in the terms that apply to ape-men crooning while grooming.)

So the upshot of the thoughts I have offered so far is not supposed to be a dogmatic view about the immovability of the manifest image, the War and Peace world. Rather, I simply want to propose that, in general, when we can't see how one real thing is connected to another-say, moral objectivity to particle physics - we should view this as an unresolved puzzle about how to connect two real things — not as a reason to doubt the reality of either of them. So also: "We don't know how our capacity for moral objectivity evolved" needn't entail "We should doubt that we have a capacity for moral objectivity"; it might just entail that there's an unanswered question about how it evolved.

I also want to recommend a pragmatic view about the weight of evidence that would be needed to move our belief in the human world, or central parts of it. In general it seems to me that nothing like that weight of evidence is typically assembled, and yet, like Tolstoy himself, we are easily moved to distance or alienate ourselves from the human world - to see it as put in doubt by the findings of science. It may even be that what drives us to do this is a kind of asceticism or misanthropy, as it seems to have been with the older Tolstoy.

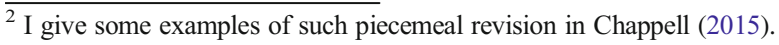


Two clear examples of the kind of under-motivated move to alienation that I am thinking of here come from philosophy of mind. One is the eliminativism about folk psychology proposed - once upon a time - by Paul Churchland. The other is classic behaviourism. In section IV of this paper I shall look more closely at these views - very briefly at eliminativism, then in more depth at behaviourism.

Pure, or crude, eliminative materialism fails to convince us because it rests on an underestimate of how much we are epistemically invested in intentional psychology, and on an overestimate of how much science, to date, has really put intentional psychology in doubt. A third thing that it rests on is a doctrine of pure observation. This doctrine is a mistake, and the mistake is one importantly shared by a number of other alienated positions, including classic behaviourism.

Classic behaviourism takes for granted the possibility of straightforward observation of behaviour. The idea - shared of course with typical statements of the classic problem of other minds, from which behaviourism seems to originate pretty directly - is that we have direct access to a class of "thin" observational facts. There is something that we just see, namely this or that bodily movement or other behavioural change. The inferential response to the problem of other minds says that from the bodily movements we infer the presence of a mind "behind" them. The behaviourist response says something different: that statements about minds just are, when properly logically analysed, statements about these bodily movements. Both view presuppose that we have direct access by pure observation to the bodily movements themselves. And that is the most fundamental mistake that both make.

It is not, of course, the only mistake that both make. Classic behaviourism is also committed to verificationism - in fact it is just the instance of verificationism that applies to minds; and verificationism is a mistake. And inferentialism about minds and behaviourism are also both guilty of giving with one hand what they take away with the other. For both presuppose that we know how to distinguish behaviour from other goings-on in the world, e.g. the doings of thermostats. But as plenty of critics have pointed out, this supposition that there is such a thing as a separable class of behaviour, events that are apt for some sort of mental analysis, seems hard to justify without a tacit assumption that we already know the difference between minded things like humans and un-minded things like thermostats, before we decide to apply the inferential or the behaviourist analysis to the minded things and not to the un-minded things. But then it looks like the inferential or the behaviourist analyses alike both presuppose their own falsity. Neither of them can work as a fully independent account of the nature of mind. Since fully independent accounts of the nature of mind is exactly what they are supposed to be, that's tantamount to saying that neither of them can work, period.

This point brings us back to what I described, above, as the deepest mistake of behaviourism, a mistake it shares with eliminative materialism. This is the mistake of supposing that there is, in general, any such thing as pure observation of "thin", public facts about behaviour on the basis of which we can postulate "thick", private facts about minds. I want to propose a quite different view of minds; I want to suggest that, outside very specialised contexts, what we observe is typically the publicity of minds, not their privacy. In making this proposal, I am, I think, doing little more than expounding the later Wittgenstein. But that's OK, first because (if you ask me) Wittgenstein is just right about this, and secondly because Wittgenstein on the publicity of the mental is still often misunderstood, as he was for example by Iris Murdoch in 
The Sovereignty of Good, and as he was by the late great Timothy Sprigge (in conversation), as proposing an essentially behaviourist view.

The central claim I want to make about the publicity of the mental - in this, as I say, simply reciting what I take to be Wittgenstein's view-is that intentions and meanings and emotions and suspicions and thoughts and sensations and pains, and in fact pretty well all other mental phenomena, are basically and essentially public. Anything about them that was not so public would not and could not be what we were talking about when we talked about intentions, meanings, sensations, etc. Like the unseen beetle in the box (PI I, 293), the hidden part of the mental phenomenon would simply drop out of consideration. (The point of that famous analogy is not, as some interpreters seem to think, that the box is empty, i.e. that we have no hidden inner processes. The point is rather that we $d o$ have processes, but they are not normally hidden or inner, and it would be pointless and self-defeating to suppose that they were.). ${ }^{3}$

Here is one simple example of the publicity of the mental. When my daughter Róisín was four, I once saw her leave her finger - unintentionally - in a slamming door. I did not infer her agony. I saw it (and heard it). Her pain was as directly perceptible to me as the slamming door was. And how directly perceptible is that? Completely directly, I would say. It is certainly a whole lot more natural to call this directly perceptible than any "sense-data", "qualia", or "phenomenal seemings" that we might like to talk about. ${ }^{4}$ Thanks to recent work on mirrorneurons in experimental psychology, we may even be beginning to get a neuropsychological handle on how we perceive each other's sensations. ${ }^{5}$

A second example of the publicity of the mental. Suppose Anna, who is married to Karenin, is watching Alexei compete in a horse-race. Her fervour in urging Alexei on has something excessive about it, something that tells everyone around her, including Karenin, that she is in love with Alexei. Anna then realises what those around her have realised. Yet it is only now, and by "reflection" from their reactions, that she realises it herself; as if she were to find out that she is blushing only by looking in a mirror. What is manifest in Anna's behaviour is more manifest to others than it is to her. ${ }^{6}$

Because intentions too are normally public in this way, the right answer to the question "How do we know what someone's intention is?" is normally "Nothing simpler". A cat stalks a bird. A deer runs toward a fence and then, seeing it, shies away. A man, as in all the old jokes, walks into a bar. Nothing is more natural for us, and few things are easier, than seeing simply from its public behaviour that some creature means to get something: the cat means to get the bird, the deer means to get out (and then discovers it can't), the man means to get a beer. In cases like these, involving humans, ${ }^{7}$ talk about intentions is at home, and (philosophy notwithstanding) uncontroversially available to us.

I said above that my daughter's pain was directly perceptible. When the aforementioned man walks into a bar, normally his intention to get a beer is directly perceptible too. (Imagine him wiping the back of his hand across his mouth as he crosses the street, licking his lips,

\footnotetext{
${ }^{3}$ Cp. L.Wittgenstein, PI I, 313: Ich kann Schmerzen vorführen, wie ich Rot vorführe, und wie ich Gerade und Krumm und Baum und Stein vorführe. Das nennen wir eben 'vorführen'.

${ }^{4}$ On this see further my "Moral Perception", Philosophy 2008.

${ }^{5}$ See e.g. Rizzolatti and Sinigaglia 2008.

${ }^{6}$ I got this example long ago, from a class that David Pugmire gave in Southampton in 1989. The story is almost but not quite in Anna Karenina, Part II, Ch.28 - hence my names. (There Karenin and other spectators at a horserace do realise Anna's passion for Vronsky from her behaviour. But Anna herself knows already.)

${ }^{7}$ PI I, 647 is not, of course, about whether non-human animals have intentions too, though it is about animalkingdom-wide continuities. From evidence elsewhere it is clear that Wittgenstein thought not, as did Aquinas (ST 1a2ae12.5), but that is not the issue here.
} 
feeling in his pocket for his wallet as he pushes at the bar-room door.) It is not, as the behaviourists used to claim, that his intention is his walking-into-a-bar behaviour, any more than Róisín's screaming and clutching of her finger in her other hand is her pain. The behaviour expresses the intention, as perfectly as a clock-face shows the time. It's not that the time is reducible to or identical with the state of the clock-face; that would be a category mistake. Yet we can normally look at the clock-face and, from it, simply recognise the time. Just likewise, we can normally simply recognise what other agents intend, what sensations they have, and the rest of it, just by observing them. "Wenn man das Benehmen des Lebewesens sieht, sieht man seine Seele" (PI I, 357).

"But Róisín might not have been in pain at all — she might have been tricking you with a grisly rubber finger she'd just bought in a Joke Shop. And the man walking into the bar might not intend to get a beer at all - he might be an actor, or an undercover detective. What are you directly seeing then?" Apparent pain, of course, or an apparent intention. The fact that these can be seen is no evidence that real pain and real intentions cannot also be seen, any more than the fact that there are forged fivers is evidence that there are no real fivers, or the fact that we seem to be able to see the right time from wrongly-set clocks is evidence that we cannot actually see the right time from rightly-set clocks. Normally with a clock, we just look and see the time. The possibility of a mistake arises afterwards. Likewise with sensations and intentions, the cases where we simply and directly observe them are the primary ones. Just as the very idea of a forged fiver depends upon the prior idea of a genuine fiver, so the idea and the possibility of a mistake about a sensation or an intention happening sometimes is built upon the prior fact that normally there isn't a mistake.

"But surely the man himself knows better than anyone else what he really intends!" If you genuinely think that, think again about my example of Anna. Or try saying it to the man's wife; she'll soon put you right. Of course there is a sense in which each of is, when things go well, peculiarly intimately related to his own intentions: as Anscombe argues in Intention, the normal way for us know our own intentions is directly and non-observationally, just like the normal way in which we know our other mental states, or know what we are doing with our own limbs and muscles. The directness and non-observationality of such self-knowledge doesn't imply its incorrigibility from other, more indirect sources. ${ }^{8}$

Again, the point is not only about intentions; it generalises across the realm of the mental. In my quasi-Karenina example, it would be futile for Anna to deny what everybody else can see about her emotional state - even if it is only because they see it that she comes to see it for herself. We can even imagine people being corrected about their own pain-sensations: the St John's Ambulance men might rush a fired-up rugby-player off the pitch, saying to her "Come on, you're in a lot of pain" - and they might be right even though she sincerely denies it. So with intentions, it is similarly futile for the man walking into the bar to deny his beerpurchasing intention, even to himself. He might say to himself "I'll just pop my head round the door and ask 'Jeff been in?'”. That is what he says, but then that is what he has said every evening for the last 25 years - and on every such occasion he has ended up staying in said bar till chucking-out time. "Thus even the most explicit expression of an intention, on its own, is not sufficient evidence of an intention.". 9

\footnotetext{
${ }^{8}$ On non-observational knowledge of one's own actions, and how it might be a species of Anscombean practical knowledge, see Haddock (2011). I am grateful to Adrian for showing me this paper.

${ }^{9}$ Wittgenstein, Philosophical Investigations I, 641: So ist also der am meisten explizite Ausdruck der Absicht allein keine genügende Evidenz der Absicht.
} 
In a host of ordinary-life cases the question arises "What have I done?"; and as the posing of the question often contextually implies, the person who asks it is not always the one bestplaced to answer it. One person says to another: "You intended X (adultery, to set the building on fire, to plagiarise another student's work, to get drunk...) You obviously intended X, so don't bother denying it" - and is absolutely right to say so. Absolutely right, no matter what the accused claims to the contrary. Absolutely right, too, even if the accused quite sincerely tells himself that adultery or arson or plagiarism etc. was not his intention. He can make little speeches in his head if he likes: "I am comforting Jean after John's demise", "I am maximising our insurance return", or whatever. These little speeches, if others get to hear them, are not irrelevant to determining the agent's exact set of mind; but as is obvious from the practice of law-courts the world over, they are not the sole or even the main evidence of anyone's intentions.

"But there are cases and cases. Of course sometimes we can tell someone what his intention is, even if he self-deceivingly denies it. That's quite different from the case where something is a necessary concomitant of what he actually intends. He might simply fail to see it. Or like Anscombe's man pumping poisoned water, he might see it and not care about it." I quite agree: of course there are cases and cases. My point is absolutely not to deny this, but rather to build on it. What I am showing here is just that the in-advance question from others "Don't you see what you're doing?", and/ or the ex-post-facto question to myself "What have I done?", give us the means of unpicking and unpacking the detail of such cases, and the different ways in which our actions may relate to or embody our intentions.

"But sometimes the only way you can tell what someone's intention is is by asking him - if even that is possible. Imagine someone, John, whose intention is to rescue a woman, Emma, from the rapist, George, whom he sees charging towards her from her left. John charges towards Emma himself, from her right, to pull her physically out of harm's way; she looks right and so sees John coming, but not George; Emma takes John for a rapist, and shoots him dead. Meanwhile George sees this happening and makes himself scarce. Such cases show that two people can make exactly the same external movements - rushing towards Emma from one side or the other-with completely different intentions. They therefore show that intentions are internal, not external."

Again, I quite agree that sometimes quite different intentions dictate identical external movements, and that there could in principle be cases where no one can tell what someone's intention was because many different intentions were compatible with his external movements, and he is no longer around to ask. (Think for instance of the controversies about Mallory and Irvine's last known movements on Everest.) To think that such cases show that intentions are never discernible from external movements is simply a crude over-generalisation. Usually, in fact, they are so discernible. Think here about the other evidence that might be relevant to settling what were John's and George's intentions in the Emma case. George's relatives might protest "You've got the wrong man - George was no rapist", and cite all sorts of evidence from his former life to prove that this was not the sort of thing that George would ever have intended. Or suppose John was apprehended after the fact, and he protested his innocent intentions; it would be quite possible for others to defeat his protests by showing e.g. how habitual rape was for him, or that he was both violent and obsessed by Emma. A court would call such evidence presumptive, because John does not actually perform his rape and George does not actually perform his rescue. But it is merely secondary? No; it is just the kind of evidence that we are always amassing about intentions. And after all, as our disbelief of John's protestation shows, a report of an intention is only presumptive evidence too. 
Because our perceptions of each other's minds are typically direct in this way, the behaviourist or inferentialist notion of "pure observation" is both unneeded and unwanted: unneeded, because we can and do perfectly well have knowledge of other minds without it; and unwanted, because it tends to mislead us by making our knowledge of other minds look far more philosophically problematic than it actually is. But now, how about this as an analogous suggestion about metaethics? The notion of a "pure fact", "thin" and "uninfected" by ethical values, is just another application of the very same notion-a notion with roots, no doubt, in the philosophy of Hume.

The moral I want to draw from this discussion of the publicity of the mental is a very quick and simple application to metaethics: it's about the widespread notion that we can rest content with the notion of a clear and exclusive distinction between the descriptive and the normative. The classic empiricist war-cry was, famously, "In reality all we ever see is..."-and then followed some claims about very simple cases of sensory perception. But outside some special contexts of abstraction, this isn't what "we see" "in reality" at all. What we see in reality is human beings interacting in what, above, I called the human world. The reality we encounter is not thin at all, but thick. And it takes an awful lot of stage-setting to get us away from that world to the "pure observation" of the empiricists. The world as we actually encounter it is a world already pervasively charged with value. If that makes it impossible for us to give a coherent and plausible statement of the supposed distinction between "fact" and "value", so much the better.

Open Access This article is distributed under the terms of the Creative Commons Attribution 4.0 International License (http://creativecommons.org/licenses/by/4.0/), which permits unrestricted use, distribution, and reproduction in any medium, provided you give appropriate credit to the original author(s) and the source, provide a link to the Creative Commons license, and indicate if changes were made.

\section{References}

Chappell T (2008) Moral perception. Philosophy 83(4):421-437

Chappell SG (2015) From metaphysics to ethics via philosophy of mind: three routes. In: Colburn B (ed) Methods of Ethics (Proceedings of the Aristotelian Society Virtual Issue Number 3)

Haddock A (2011) The knowledge that a man has of his intentional actions. In: Anton F, Jennifer H, Frederick S (eds) Essays on Anscombe's Intention. Harvard University Press, Cambridge, pp 147-169

Rizzolatti G, Sinigaglia C (2008) Mirrors in the brain: how we share our actions and emotions. Oxford University Press

Stich S (1983) From folk psychology to cognitive science. MIT Press, Cambridge 